\title{
Environmental correlates of peatland carbon fluxes in a thawing landscape: do transitional thaw stages matter?
}

\author{
A. Malhotra and N. T. Roulet \\ Department of Geography, McGill University, Montreal, Quebec, Canada \\ Correspondence to: A. Malhotra (avni.malhotra@mail.mcgill.ca)
}

Received: 30 November 2014 - Published in Biogeosciences Discuss.: 8 January 2015

Revised: 15 April 2015 - Accepted: 4 May 2015 - Published: 29 May 2015

\begin{abstract}
Peatlands in discontinuous permafrost regions occur as a mosaic of wetland types, each with variable sensitivity to climate change. Permafrost thaw further increases the spatial heterogeneity in ecosystem structure and function in peatlands. Carbon (C) fluxes are well characterized in endmember thaw stages such as fully intact or fully thawed permafrost but remain unconstrained for transitional stages that cover a significant area of thawing peatlands. Furthermore, changes in the environmental correlates of $\mathrm{C}$ fluxes, due to thaw, are not well described - a requirement for modeling future changes to $\mathrm{C}$ storage of permafrost peatlands. We investigated $C$ fluxes and their correlates in end-member and a number of transitional thaw stages in a sub-arctic peatland. Across peatland-lumped $\mathrm{CH}_{4}$ and $\mathrm{CO}_{2}$ flux data had significant correlations with expected correlates such as water table depth, thaw depth, temperature, photosynthetically active radiation and vascular green area. Within individual thaw states, bivariate correlations as well as multiple regressions between $\mathrm{C}$ flux and environmental factors changed variably with increasing thaw. The variability in directions and magnitudes of correlates reflects the range of structural conditions that could be present along a thaw gradient. These structural changes correspond to changes in $\mathrm{C}$ flux controls, such as temperature and moisture, and their interactions. Temperature sensitivity of $\mathrm{CH}_{4}$ increased with increasing thaw in bivariate analyses, but lack of this trend in multiple regression analyses suggested cofounding effects of substrate or water limitation on the apparent temperature sensitivity. Our results emphasize the importance of incorporating transitional stages of thaw in landscape level $\mathrm{C}$ budgets and highlight that end-member or adjacent thaw stages do not adequately describe the variability in structure-function relationships present along a thaw gradient.
\end{abstract}

\section{Introduction}

Northern permafrost regions contain approximately $50 \%$ $(1672 \mathrm{Pg})$ of the world's soil carbon (C) pool and peatlands store $277 \mathrm{Pg}$ of this C (Schuur et al., 2008; Tarnocai et al., 2009). Thawing permafrost is projected to act as a positive feedback to climate change via the release of soil $\mathrm{C}$ to the atmosphere and the magnitude of this feedback remains uncertain (Schuur et al., 2013). Peatlands in the permafrost regions are currently experiencing increased rates of thaw and related changes to abiotic and biotic components (structure) and elemental cycling (function; Camill, 2005; Osterkamp, 2005). Thawing peatlands are a mosaic of different wetland types, ranging from permanently frozen (e.g., palsa) to permafrost-free and minerotrophic fens (Luoto et al., 2004). Each component of these heterogeneous landscapes has distinct $\mathrm{C}$ function, contributing to uncertainties in estimating landscape level $\mathrm{C}$ budgets. Constraining the spatial variability in peatland $\mathrm{C}$ fluxes and related abiotic and biotic factors, is an essential step toward estimating the positive feedback potential of thawing permafrost on climate change.

Permafrost thaw in peatlands is associated with marked changes in ecosystem structure and function. Initial ground subsidence from thaw results in wet habitats due to a high water table (Smith et al., 2012). Relative to dry areas, the seasonal frost table thaws faster in wet areas, further increasing lateral flow of water to wet areas (Quinton et al., 2009). The increase in water table depth (WTD) leads to a vegetation shift toward wetter communities and an increase in graminoid species (Camill, 1999; Camill et al., 2001; Malmer et al., 2005). Rapid changes also occur in the microbial community, notably an increased activity of methane $\left(\mathrm{CH}_{4}\right)$ and nitrogen cycling (Mackelprang et al., 2011). Associated with structural shifts, several functional changes 
have been observed in thawed permafrost peatlands. Typically plant productivity increases (Vogel et al., 2009), but so does autotrophic and heterotrophic respiration (Hicks Pries et al., 2013). Organic matter decomposition may decrease due to increased anoxic conditions after ground subsidence (Camill et al., 2001). Thus, there could be an initial increase in organic matter accumulation as a result of permafrost thaw (Turetsky et al., 2007; Vitt et al., 2000). Subsequently, decomposition may increase due to the increase in easily decomposable litter from community shifts toward more vascular plants (Hodgkins et al., 2014; Turetsky, 2004) and quantity of litter (Malmer et al., 2005). Regardless of the initial increase in $\mathrm{C}$ accumulation, the net radiative forcing of a recently thawed area is offset by an increase in $\mathrm{CH}_{4}$ emissions (Johansson et al., 2006; Sitch et al., 2007; Turetsky et al., 2007). This increase in $\mathrm{CH}_{4}$ emissions may be a direct result of increased temperature on microbial processes or indirect consequences such as increases in plant mediated transport of $\mathrm{CH}_{4}$ by increased graminoid abundance and increased anaerobic decomposition due to a high water table (Christensen et al., 2004). In addition to magnitude, the dominant pathway of $\mathrm{CH}_{4}$ production is also altered after thaw, shifting from $\mathrm{CO}_{2}$ reduction (hydrogenotrophic) to acetate cleavage .(acetoclastic; Hodgkins et al., 2014; McCalley et al., 2014). The change in pathway is likely related to shifts in vegetation, for example, a decrease in Sphagnum abundance could lead to an increase in $\mathrm{pH}$ and related increase in acetoclastic methanogens (Hines et al., 2008; Ye et al., 2012). Dissolved organic matter (DOM) is also more labile in the more thawed stages, and there is increased export of DOM out of the peatland catchment (Hodgkins et al., 2014; Olefeldt and Roulet, 2012, 2014). Recent studies highlight the interactive controls on $C$ fluxes, emphasizing that net radiative forcing of a thawing ecosystem depends on non-linear interactions among temperature, degree of anoxia and organic matter chemistry (Lee et al., 2012; Treat et al., 2014). For example, while temperature sensitivity of $\mathrm{CH}_{4}$ flux increases in wet habitats (Olefeldt et al., 2013), ecosystem respiration is more sensitive in dry conditions (McConnell et al., 2013). Interactive controls on $\mathrm{C}$ fluxes are further complicated by the variable structural conditions as thaw progresses, and the overall effect on landscape level fluxes remains unconstrained.

Changes to peatland structure and function due to permafrost degradation have been studied using a chronosequence approach with sites that have intact permafrost, completely thawed permafrost and one or two intermediate stages (e.g., Bäckstrand et al., 2010; Turetsky et al., 2007; Vogel et al., 2009). While end-member and major thaw stages of the permafrost gradient have been well characterized for plant community structure and carbon cycling, the same is not true for the transitional vegetation communities. Carbon cycling in thawing permafrost regions is spatially heterogeneous (e.g., Belshe et al., 2012; Morrissey and Livingston, 1992; Zhang et al., 2012) and a significant portion of the landscape is in varying stages of thaw. Spatial heterogeneity and transitional stages are therefore important to the ecosystem level $\mathrm{C}$ exchanges. It is unclear whether 3 to 5 thaw classes of intact, intermediate and fully thawed permafrost can be used to adequately extrapolate landscape scale $\mathrm{C}$ fluxes and their abiotic and biotic correlates. Additional thaw stages may help resolve landscape scale $\mathrm{C}$ fluxes in models.

Our study aims to identify the abiotic and biotic factors (hereafter, correlates) that relate to $\mathrm{C}$ function and investigate how these correlates change along end-member and transitional permafrost thaw stages. Our research questions are the following: (1) which correlates best explain the $\mathrm{CH}_{4}$ and $\mathrm{CO}_{2}$ fluxes across all thaw stages at a peatland where permafrost is thawing? (2) How does the importance of these correlates change along a gradient of increasing thaw? Our selection of measured correlates was based on current understanding of $\mathrm{C}$ flux relationships with temperature, moisture, $\mathrm{pH}$, nutrients and plant biomass. Given the interactive nature of controls on $\mathrm{C}$ fluxes and variable structural changes after thaw, we expected to see no relationship between dominant correlates of $\mathrm{C}$ flux and degree of thaw.

\section{Methods}

\subsection{Study site}

The study site, Stordalen mire is located $10 \mathrm{~km}$ east of Abisko in Sweden $\left(68^{\circ} 22^{\prime} \mathrm{N}, 19^{\circ} 03^{\prime} \mathrm{E}\right)$. The Stordalen peatland complex consists of several landscape units and wetland types. Permafrost is present in the dry hummocky sections of the peatland (palsa mire). Also present are areas where permafrost is thawing or has disappeared with vegetation communities that have been classified as semi-wet, wet, and tall graminoid (Johansson et al., 2006; Kvillner and Sonesson, 1980). Generally, the drier areas of the peatland complex are composed of species such as Empetrum hermaphroditum, Betula nana, Rubus chamaemorus, Eriophorum vaginatum, Dicranum elongatum and Sphagnum fuscum. The wetter areas consist of species such as E. vaginatum, Carex rotundata, S. balticum, E. angustifolium, C. rostrata, S. lindbergii, and $S$. riparium. The long term (1912-2003) mean precipitation measured at the Abisko Scientific Research Station ( $10 \mathrm{~km}$ from the site) is $303.3 \mathrm{~mm}$, of which $150 \mathrm{~mm}$ occurs between June and September. The long term (1912-2009) mean annual temperature at the site is $-0.5^{\circ} \mathrm{C}$ but has surpassed $0^{\circ} \mathrm{C}$ in the recent decades (summarized in Olefeldt and Roulet 2012, from observations made at Abisko Scientific Research Station). Smoothed mean annual temperature trends suggest a $2.5^{\circ} \mathrm{C}$ increase between 1913 and 2006. (Callaghan et al., 2010). 
Table 1. Details of each thaw stage - habitat description and dominant vegetation, vascular plant green area (VGA), presence or absence of permafrost, mean growing season water table depth (from 19 days of sampling over 2 years), mean surface water $\mathrm{pH}$, reduced conductivity (Cond) and $\mathrm{C}: \mathrm{N}$ ratio, growing season mean soil temperature at $10 \mathrm{~cm}$ depth below surface and mean growing season $\mathrm{CH}_{4}$ fluxes. Details on $\mathrm{CO}_{2}$ flux for each thaw stage can be found in Table 4. WTD was only reported for stages with a water table on more than 5 sampled days. All values reported after \pm are standard errors.

\begin{tabular}{|c|c|c|c|c|c|c|c|c|c|}
\hline $\begin{array}{l}\text { Thaw } \\
\text { stage }\end{array}$ & $\begin{array}{l}\text { Habitat description and } \\
\text { dominant vegetation }\end{array}$ & $\begin{array}{l}\text { Mean VGA } \\
\left(\mathrm{cm}^{2}\right)\end{array}$ & $\begin{array}{l}\text { Perma- } \\
\text { frost }\end{array}$ & $\begin{array}{l}\text { Mean } \\
\text { WTD }(\mathrm{cm})\end{array}$ & $\mathrm{pH}$ & $\begin{array}{l}\text { Cond } \\
\left(\mathrm{mgL}^{-1}\right)\end{array}$ & $\mathrm{C}: \mathrm{N}$ & $\begin{array}{l}\text { Mean soil } \\
\text { temperature }\left({ }^{\circ} \mathrm{C}\right)\end{array}$ & $\begin{array}{l}\text { Mean } \mathrm{CH}_{4} \text { flux } \\
\left(\mathrm{mg} \mathrm{m}^{-2} \text { day }^{-1}\right)\end{array}$ \\
\hline 1 & $\begin{array}{l}\text { Intact palsa, Dicranum elongatum, Vaccinium } \\
\text { uliginosum }\end{array}$ & 279.6 & $\sqrt{ }$ & - & - & - & - & $6.2 \pm 0.2$ & $-1.3 \pm 0.2$ \\
\hline 2 & $\begin{array}{l}\text { Slightly thawing palsa, D. elongatum, Eriophorum } \\
\text { vaginatum, Ptillidium ciliare }\end{array}$ & 232.7 & $\sqrt{ }$ & - & - & - & - & $6.7 \pm 0.2$ & $7.1 \pm 1.1$ \\
\hline 3 & $\begin{array}{l}\text { Collapsing palsa, desiccated Sphagnum fuscum, } \\
\text { lichens, Andromeda polifolia }\end{array}$ & 66.7 & $\sqrt{ }$ & - & - & - & - & $6.6 \pm 0.2$ & $-1.1 \pm 0.3$ \\
\hline 4 & $\begin{array}{l}\text { Sphagnum lawn in transition between stages } 3 \text { and } \\
5\end{array}$ & 54.0 & - & $-11.6 \pm 1.3$ & - & - & - & $8.3 \pm 0.3$ & $7.6 \pm 1.4$ \\
\hline 5 & Sphagnum lawn & 60.3 & - & $-10.1 \pm 0.7$ & 4.0 & 8.0 & 35.8 & $7.2 \pm 0.3$ & $18.7 \pm 2.7$ \\
\hline 6 & Sphagnum lawn, Betula nana & 312.1 & - & $-11.5 \pm 0.6$ & - & - & - & $8.1 \pm 0.4$ & $29.5 \pm 4.8$ \\
\hline 7 & E. vaginatum, S. cuspidatum, open water & 334.4 & - & $-2.3 \pm 0.6$ & 4.1 & 17.0 & 45.3 & $9.9 \pm 0.3$ & $56.5 \pm 3.5$ \\
\hline 8 & $\begin{array}{l}\text { E. vaginatum, Drepanocladus schulzei, open wa- } \\
\text { ter }\end{array}$ & 322.0 & - & $1.8 \pm 0.9$ & 4.0 & 76.2 & 47.9 & $10.4 \pm 0.3$ & $102.4 \pm 7.5$ \\
\hline 9 & Eriophorum angustifolium, open water & 1136.3 & - & $2.3 \pm 0.6$ & 4.5 & 30.0 & 46.6 & $7.6 \pm 0.3$ & $370.2 \pm 52.1$ \\
\hline 10 & Polytrichum jensenii, Carex rostrata & 1528.7 & - & $-5.8 \pm 1.3$ & 4.7 & 22.6 & 53.0 & $7.2 \pm 0.3$ & $266.2 \pm 22.7$ \\
\hline
\end{tabular}

\subsection{Vegetation community and thaw stage selection}

A total of 10 vegetation communities were selected across Stordalen to represent major stages along the thaw gradient. Selection of communities was based on an across site survey of dominant vegetation communities, coupled with characterization of water table depth and active layer thickness. The sequence of the 10 thaw stages was based on a survey of spring thaw depth and previously established vegetation community relationships with permafrost thaw (Johansson et al., 2006; Kvillner and Sonesson, 1980).

\subsection{Gas flux measurements}

Within each of the 10 selected communities, 3 collars of $0.05 \mathrm{~m}^{2}$ area each were inserted in the peat surface and served as a seal for the manual gas flux measurements, with the exception of 2 communities that had only 2 collars each as they represent a small area in the mire (Table 1). Each community also had a PVC dip well installed to measure the water table depth.

Methane flux was measured using opaque chambers of volume 9 or $18 \mathrm{~L}$. Five headspace gas samples of $20 \mathrm{~mL}$ each were collected every $5 \mathrm{~min}$ over $20 \mathrm{~min}$. Prior to collecting each sample, the headspace was mixed using a syringe. The collected headspace samples were analyzed within $24 \mathrm{~h}$ for concentrations of $\mathrm{CH}_{4}$ using a Shimadzu GC-2014 gas chromatograph with a flame ionization detector, after separation on a HayeSep-Q packed column at the Abisko Scientific Research Station. Helium was used as a carrier gas at the flow rate of $30 \mathrm{~mL} \mathrm{~min}^{-1}$. Injector, column and detector temperatures were 120,40 and $120^{\circ} \mathrm{C}$, respectively. A 10-repetition run of known $\mathrm{CH}_{4}$ standard ( 2 ppm concentration) was used to calibrate the GC before and after each sample run. Accu- racy of the analysis (calculated with the standard deviation of the 10 standard replicates) was \pm 0.1 to $0.75 \%$. Flux rates were then calculated using the slope of the linear relationship between gas concentrations and time. Only the relationships with a significant $(p<0.05) R^{2}$ above 0.85 for the five time points were kept to calculate fluxes. If one of the five samples deviated from the linear fit, flux was calculated without it as long as the $R^{2}$ was greater than 0.95 . Methane was measured on 7 days and 12 days in the 2012 and 2013 growing seasons, respectively.

For carbon dioxide flux measurements on the 28 collars, we used clear cylindrical polycarbonate chambers $(13 \mathrm{~L}$ volume). The air enclosed within the chambers was mixed by fans and circulated through an infrared gas analyzer (PP Systems, Model EGM-4) that measured changes in $\mathrm{CO}_{2}$ over 3 -min measurement intervals (recording every $10 \mathrm{~s}$ for the first minute, and then every $30 \mathrm{~s}$ for the last $2 \mathrm{~min}$ ). Over the $3 \mathrm{~min}$ measurement period, on average, temperature in the chamber only increased by $1.9^{\circ} \mathrm{C}$. Measurements were performed for full sun, with a mesh cover and finally with a black shroud, so that data from varying light intensities could be collected. Photosynthetically active radiation (PAR) was measured (Model LI-190SA, LI-COR ${ }^{\circledR}$, NE, USA) within each chamber over the sample interval. Fluxes were calculated using a linear regression of $\mathrm{CO}_{2}$ concentration change over time. $\mathrm{CO}_{2}$ was sampled on 10 days during the 2013 growing season.

\subsection{Ancillary measurements}

Each flux measurement of $\mathrm{CO}_{2}$ or $\mathrm{CH}_{4}$ was coupled with simultaneous measurements of soil temperature at $10 \mathrm{~cm}$, air temperature, thaw depth and water table depth (WTD). Once during the 2012 growing season, elevation (above sea 
level) of each collar was measured using a real-time kinematic (RTK)-GPS.

Vegetation composition for vascular plants was surveyed once every growing season in each of the collars recording the percent cover of each species. In 2013, vascular green area (VGA) was also measured on 4 days during the growing season using species specific formulae based on leafgeometry (Lai, 2012; Wilson et al., 2006). For each collar, the total number of green leaves per species was recorded along with width and length of 10 leaves for each species. The seasonality of VGA was modeled using a Gaussian fit and combined with a quadratic fit with elevation to extrapolate a spatially and temporally higher resolution data set for VGA. Throughout the manuscript we only use the modeled VGA.

Surface water was sampled near the collars on each $\mathrm{CH}_{4}$ sampling day in thaw stages that had persistent water table throughout the growing season (Thaw stages 5, 7, 8, 9 and 10). Surface water samples were analyzed for $\mathrm{pH}$ and conductivity (Oakton ${ }^{\circledR}$ portable $\mathrm{pH}$ conductivity meter) and reduced conductivity was calculated by removing $\mathrm{H}$ ion concentrations from the conductivity. Subsequently, samples were filtered using Whatman ${ }^{\circledR}$ glass fiber filters $(0.45 \mu \mathrm{m}$ pore size) and analyzed for dissolved organic carbon and total nitrogen using a Shimadzu TOC-V Series Analyzer.

\subsection{Data analyses}

$\mathrm{CH}_{4}$ flux - each flux measurement was $\log _{10}$ transformed after adding $12 \mathrm{mg} \mathrm{CH}_{4} \mathrm{~m}^{-2} \mathrm{~d}^{-1}$ to the original value (to account for all the negative fluxes). $\log _{10}$ transformation decreased the skew in the raw data and improved the linear relationship between $\mathrm{CH}_{4}$ and other variables, allowing for the use of multiple linear regressions. Bivariate relationships with abiotic and biotic factors were explored with Spearman's rank-order correlations. To explore the relationship between environmental correlates and $\mathrm{CH}_{4}$ flux, we used stepwise multiple linear regression. We used both additive and interactive effects to explore a best fit model, but found that interactive effects were either insignificant or had a weak contribution to the overall model. For ease of interpretation, given that our variables are already proxies for several interacting controls on $\mathrm{CH}_{4}$ fluxes, we only included additive effects in our final model. The best fit model met the necessary assumptions of normality and homoscedasticity of model residuals. Multicollinearity was checked using variance inflation factors (VIFs), wherein any explanatory variable with VIFs greater than 2 was removed from the model.
Arrhenius plots were utilized to study the temperature sensitivity of $\mathrm{CH}_{4}$ flux, regressing the $\log$ of $\mathrm{CH}_{4}$ flux with inverse of temperature in Kelvin.

$\mathrm{CO}_{2}$ flux - we combined all $\mathrm{CO}_{2}$ flux data using nonlinear regression of a rectangular hyperbola to describe the relationship of net ecosystem exchange (NEE) and PAR (Bubier et al., 2003):

$\mathrm{NEE}=\frac{\mathrm{GP}_{\mathrm{MAX}} \times \mathrm{PAR} \times \alpha}{\mathrm{PAR} \times \alpha+\mathrm{GP}_{\mathrm{MAX}}}+A$.

The parameters are the following;

- GP $\mathrm{MAX}$ : the maximum gross photosynthetic $\mathrm{CO}_{2}$ capture at maximum PAR $\left(\mu \mathrm{mol} \mathrm{CO} \mathrm{CO}^{-2} \mathrm{~s}^{-1}\right)$;

$-\alpha$ : the photosynthetic quantum efficiency $\left(\mu \mathrm{mol} \mathrm{CO}_{2}\right.$ $\mathrm{m}^{-2} \mathrm{~s}^{-1}$ per $\mu \mathrm{mol}$ PAR $\mathrm{m}^{-2} \mathrm{~s}^{-1}$ );

- $A$ : the dark respiration at $0^{\circ} \mathrm{C}\left(\mu \mathrm{mol} \mathrm{CO} \mathrm{CO}_{2} \mathrm{~m}^{-2} \mathrm{~s}^{-1}\right)$.

Other than PAR, we expected to see non-linear relationships between $\mathrm{CO}_{2}$ flux and WTD, thaw depth, soil temperature and VGA, but we did not find significant relationships. Instead we found linear relationships to be significant. Since our data were non-parametric, we used Spearman's correlation coefficients to quantify the link between $\mathrm{CO}_{2}$ flux with abiotic and biotic variables.

Thaw gradient analyses - above analyses for $\mathrm{CH}_{4}$ and $\mathrm{CO}_{2}$ were repeated independently for each of the 10 thaw stages. Subsequently, strength (adjusted $R^{2}$ or Spearman's $\rho$ ) and direction of relationships between correlates and function variables were organized by thaw stage to observe whether there is a significant trend in changing correlates of $\mathrm{CH}_{4}$ and $\mathrm{CO}_{2}$ fluxes along the thaw gradient. The sequence of thaw stages along the gradient was based on a survey of spring thaw depth, as discussed in section 2.2. Multiple regressions were also performed for each thaw stage since $\mathrm{CH}_{4}$ and $\mathrm{CO}_{2}$ fluxes are not typically estimated using bivariate models. While the bivariate correlations identified how the dominant correlates change across the thaw gradient, multiple regressions across the thaw gradient provide a better idea of the changing interactive effects of abiotic and biotic correlates on $\mathrm{CH}_{4}$ or $\mathrm{CO}_{2}$ fluxes.

Lastly, we evaluated the relationship between $\mathrm{CH}_{4}$ and $\mathrm{CO}_{2}$ fluxes using a simple $\mathrm{CH}_{4}: \mathrm{CO}_{2}$ flux ratio. For a standardized measure of $\mathrm{CO}_{2}$ flux we use the $\mathrm{GP}_{\mathrm{MAX}}$ from each thaw stage.

\section{Results}

\subsection{Across peatland $\mathrm{C}$ fluxes and correlates}

Mean and standard error of $\mathrm{CH}_{4}$ flux across all collars from 2 years of sampling was $91.25 \pm 8.17 \mathrm{mg} \mathrm{CH}_{4} \mathrm{~m}^{-2} \mathrm{~d}^{-1}$, ranging from $-1.1 \pm 0.3$ to $370.2 \pm 52.1 \mathrm{mg} \mathrm{CH}_{4} \mathrm{~m}^{-2} \mathrm{~d}^{-1}$ (Table 1). 


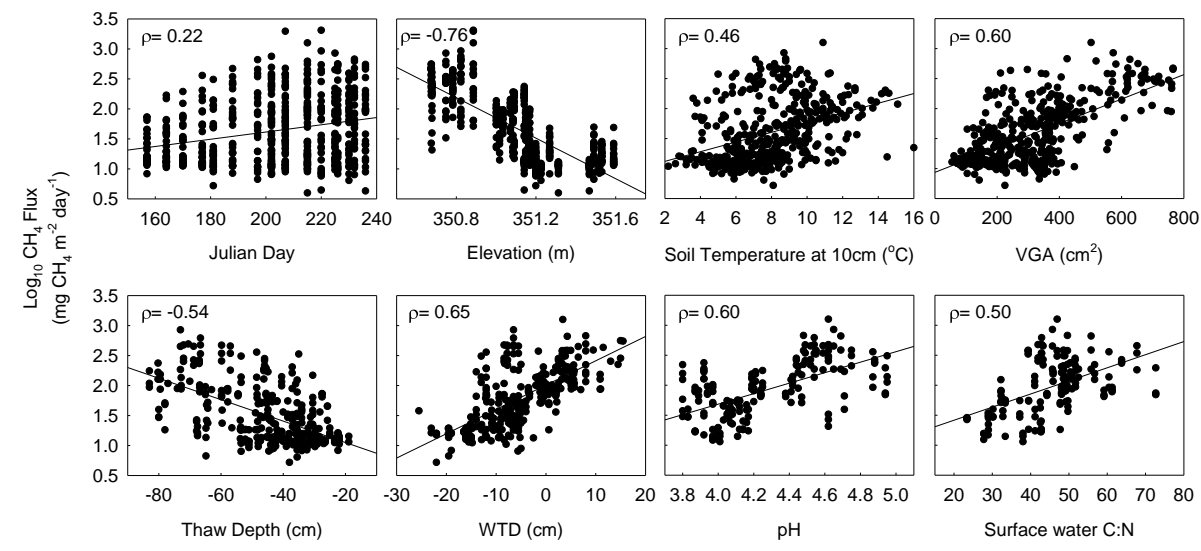

Figure 1. Relationship between $\mathrm{CH}_{4}$ fluxes and environmental variables (across peatland-lumped data). Flux data lumped from 28 sampled collars from 2 years (19 days of sampling) showed significant relationships with Julian day, elevation (above sea level) of collar, soil temperature at $10 \mathrm{~cm}$ depth below surface, modeled VGA (vascular green area), water table depth (WTD), $\mathrm{pH}$, thaw depth and C: N of surface water. Spearman's $\rho$ of each correlation are shown on each graph $(p<0.0001)$.

Table 2. Best fit model of $\mathrm{CH}_{4}$ flux across the site. Listed environmental variables explain $73 \%$ of the variance in $\mathrm{CH}_{4}$ flux $\left(R^{2}=0.73, F_{4,391}=267.1, p<0.0001\right)$.

\begin{tabular}{lllll}
\hline Term & Estimate & Std error & $t$ ratio & Prob $>|t|$ \\
\hline Intercept & 344.38 & 26.94 & 12.8 & $<0.0001$ \\
Elevation & -0.98 & 0.077 & -12.8 & $<0.0001$ \\
Soil temp & 0.031 & 0.007 & 4.43 & $<0.0001$ \\
Thaw depth & -0.005 & 0.001 & -8.50 & $<0.0001$ \\
VGA & 0.001 & 0.000 & 7.09 & $<0.0001$ \\
\hline
\end{tabular}

Strongest bivariate relationships between $\mathrm{CH}_{4}$ flux and abiotic variables were with elevation, water table depth, $\mathrm{pH}$, VGA, thaw depth and surface water C: N (Fig. 1). Significant but weaker relationships were also found with soil temperature and Julian day. Total carbon (TC), total nitrogen (TN), conductivity and reduced conductivity did not have a significant relationship with $\mathrm{CH}_{4}$ flux.

The best fit multiple regression model for $\mathrm{CH}_{4}$ fluxes across the peatland included elevation, thaw depth, VGA and soil temperature, in decreasing order of contribution to the overall model, and these variables were able to explain $73 \%$ of the variance in $\mathrm{CH}_{4}$ flux (Table 2). An alternative model that excluded elevation wherein the adjusted $R^{2}$ drops to 0.62 , is also reported as it better isolated the effects of VGA, soil temperature and thaw depth. The contribution (beta weights reported in brackets) of soil temperature (0.16) and thaw depth $(-0.27)$ are similar in the model with or without elevation. The contribution of VGA increases from 0.26 to 0.58 when elevation is removed from the model.

Photosynthetically active radiation showed the strongest relationship with $\mathrm{CO}_{2}$ fluxes, explaining $55 \%$ of the variance observed in the flux data (Fig. 2). The rectangular hyperbola fit of NEE against PAR, Eq. (1), provided
Table 3. Abiotic and biotic relationships with gross primary production (GPP $=$ NEE $\left.-R_{\text {eco }}\right)$, net ecosystem exchange (NEE) and ecosystem respiration $\left(R_{\text {eco }}\right)$. $R_{\text {eco }}$ has negative values and therefore, negative correlation signifies that larger VGA or soil temp have higher $R_{\text {eco }}$. Similarly, since thaw depth has negative values, negative correlations with GPP and NEE mean that deeper frost tables relate to greater GPP and NEE.

\begin{tabular}{llll}
\hline Function & Correlate & Spearman's $\rho$ & $p$ value \\
\hline NEE & thaw depth & -0.21 & 0.0058 \\
NEE & soil temp & 0.14 & 0.0112 \\
NEE & WTD & 0.24 & 0.0002 \\
NEE & VGA & 0.58 & 0.0180 \\
GPP & thaw depth & -0.29 & 0.0020 \\
GPP & WTD & 0.20 & 0.0177 \\
$R_{\text {eco }}$ & Soil Temp & -0.16 & 0.0226 \\
$R_{\text {eco }}$ & VGA & -0.56 & 0.0250 \\
\hline
\end{tabular}

the following parameter estimates and standard errors for the across site-lumped data: $\mathrm{GP}_{\mathrm{MAX}}$ was $4.24 \pm 0.26 \mu \mathrm{mol}$ $\mathrm{CO}_{2} \mathrm{~m}^{-2} \mathrm{~s}^{-1}, \quad \alpha$ was $0.027 \pm 0.005 \mu \mathrm{mol} \quad \mathrm{CO}_{2} \mathrm{~m}^{-2} \mathrm{~s}^{-1}$ per $\mu \mathrm{mol}$ PAR m ${ }^{-2} \mathrm{~s}^{-1}$ and $A$ was $-1.78 \pm 0.09 \mu \mathrm{mol}$ $\mathrm{CO}_{2} \mathrm{~m}^{-2} \mathrm{~s}^{-1}$.

Water table depth and thaw depth showed weak relationships with NEE and gross primary production (GPP) (calculated using NEE minus $R_{\text {eco }}$; Table 3 ). Soil temperature was also related to $R_{\text {eco }}$ and NEE. NEE and $R_{\text {eco }}$ were most strongly related to the mean growing season VGA (Table 3 ).

\subsection{Correlate-flux relationships within the thaw stages}

Along the thaw gradient, the strength and direction of bivariate relationships among environmental variables and $\mathrm{CH}_{4}$ flux changed variably (Fig. 3). No significant trend along the thaw gradient was observed for the relationship between $\mathrm{CH}_{4}$ 
Table 4. Parameter estimates \pm standard error from rectangular hyperbola fit of NEE and PAR. PAR dependence of NEE generally increases and becomes more significant from less to more thawed stages as shown by the adjusted $R^{2}$ ( $p<0.0001$ for all thaw stages). There is a general trend of increasing, $\mathrm{GP}_{\mathrm{MAX}}, \alpha$ and $A$, going from less thawed to more thawed stages.

\begin{tabular}{|c|c|c|c|c|c|}
\hline $\begin{array}{l}\text { Thaw } \\
\text { Stage }\end{array}$ & $\begin{array}{c}\mathrm{GP}_{\mathrm{MAX}} \\
\left(\mu \mathrm{molCO} \mathrm{m}^{-2} \mathrm{~s}^{-1}\right)\end{array}$ & $\begin{array}{c}\alpha \\
\left(\mu \mathrm{molCO} 2 \mathrm{~m}^{-2} \mathrm{~s}^{-1}\right) \\
\left(\mu \mathrm{molPAR} \mathrm{m}^{-2} \mathrm{~s}^{-1}\right)^{-1}\end{array}$ & $\begin{array}{c}A \\
\left(\mu \mathrm{molCO} \mathrm{m}^{-2} \mathrm{~s}^{-1}\right)\end{array}$ & $R^{2}$ & $n$ \\
\hline 1 & $3.85 \pm 1.21$ & & $-4.36 \pm 0.53$ & 0.59 & 26 \\
\hline 2 & $3.99 \pm 0.53$ & $0.015 \pm 0.004$ & $-1.72 \pm 0.16$ & 0.71 & 75 \\
\hline 3 & $2.82 \pm 0.61$ & $0.008 \pm 0.003$ & $-1.52 \pm 0.13$ & 0.80 & 26 \\
\hline 4 & $2.44 \pm 0.31$ & $0.014 \pm 0.005$ & $-0.89 \pm 0.11$ & 0.76 & 52 \\
\hline 5 & $3.87 \pm 0.30$ & $0.030 \pm 0.007$ & $-1.28 \pm 0.11$ & 0.85 & 78 \\
\hline 6 & $5.15 \pm 0.52$ & $0.053 \pm 0.021$ & $-2.76 \pm 0.25$ & 0.89 & 27 \\
\hline 7 & $6.28 \pm 0.72$ & $0.032 \pm 0.010$ & $-1.79 \pm 0.24$ & 0.74 & 78 \\
\hline 8 & $2.15 \pm 0.24$ & $0.015 \pm 0.005$ & $-0.94 \pm 0.09$ & 0.82 & 98 \\
\hline 9 & $8.16 \pm 0.86$ & $0.072 \pm 0.023$ & $-3.49 \pm 0.32$ & 0.91 & 27 \\
\hline 10 & $6.62 \pm 1.34$ & & $-5.35 \pm 0.82$ & 0.69 & 18 \\
\hline
\end{tabular}

Table 5. Multiple regression model of $\mathrm{CH}_{4}: \mathrm{CO}_{2}$ explained by percent cover of Sphagnum and soil temperature. $\left(R^{2}=0.82, F_{3,11}=\right.$ $11.9, p=0.002)$. Slope estimates and standard errors (SE) are reported along with $t$ ratio and associated $p$ value.

\begin{tabular}{lllll}
\hline & Estimate & $\mathrm{SE}$ & $t$ ratio & $p$ value \\
\hline Intercept & 313.4 & 71.8 & 4.37 & 0.0024 \\
Soil temperature & -35.2 & 9.5 & -3.72 & 0.0059 \\
$\%$ Sphagnum & -0.39 & 0.1 & -4.50 & 0.0020 \\
Soil temp $\times$ \% Sphagnum & 1.79 & 0.6 & 3.19 & 0.0128 \\
\hline
\end{tabular}

flux and elevation, VGA (vascular green area) and WTD. Significant trends were observed with the water chemistry variables of $\mathrm{pH}, \mathrm{C}: \mathrm{N}, \mathrm{TC}, \mathrm{TN}$ and conductivity and strength of correlations between correlate and $\mathrm{CH}_{4}$ flux increased as the permafrost thawed. However, these data were only available for thaw stages with a water table (thaw stages 5 to 10). Soil temperature, thaw depth and Julian day, with data available for each of the 10 thaw stages, showed significant trends along the thaw gradient in their correlation with the $\mathrm{CH}_{4}$ flux (Fig. $4 a, b$, and c). There was an increase in the amount of variance explained in the $\mathrm{CH}_{4}$ flux by temperature as well as the slope of this relationship (Fig. 5).

The parameter estimates from the best fit model of across peatland-lumped flux data, as shown in Table 2, were used as inputs for individual multiple regression models for each thaw stage. The interactive effects of elevation, soil temperature, thaw depth and vascular green area (VGA) showed varying results across the thaw gradient (Fig. 6). The model $R^{2}$ values ranged from 0.09 (insignificant) to 0.79 (significant with $p<0.0001$ ). Generally, elevation, soil temperature, thaw depth and VGA were better predictors of variance in $\mathrm{CH}_{4}$ fluxes in the later stages of thaw. Model fit was nonsignificant for stages 2 and 3, and therefore their slope coefficients are not reported in Fig. 6.
The relationship of NEE with temperature and with PAR varied across the thaw gradient without a statistically significant trend. Generally there is a trend of increasing, GP $\mathrm{MAX}$, $\alpha$ and A, going from less thawed to more thawed stages (Table 4). Furthermore, the amount of variance of NEE explained by PAR was typically higher in the more thawed stages.

\subsection{Relationship between NEE and $\mathrm{CH}_{4}$}

$\mathrm{GP}_{\text {MAX }}$ and $\mathrm{CH}_{4}$ were positively correlated $(\rho=0.56, p=$ 0.0021 ; Fig. 7). We found that the best explanatory variables for $\mathrm{CH}_{4}$ : $\mathrm{GP}_{\text {MAX }}$ ratio were Sphagnum percent cover $(\rho=-0.72, p=0.008$; and graminoid VGA $(\rho=0.63, p=$ $0.0004)$. While graminoid VGA did not have any interactive effects with abiotic variables in explaining $\mathrm{CH}_{4}$ : GP MAX ratio, Sphagnum cover and soil temperature had a significant interactive effect (Table 5)

\section{Discussion}

We identified the major abiotic and biotic correlates of the ecosystem - atmospheric exchanges of $\mathrm{CO}_{2}$ and $\mathrm{CH}_{4}$ across Stordalen mire and found that, as per our expectation, these environment-function relationships changed variably across the thaw gradient, suggesting that correlates of $\mathrm{CO}_{2}$ and $\mathrm{CH}_{4}$ fluxes in transitional stages are not necessarily represented well by correlates of the end-member or adjacent thaw stages. Contrary to our expectation, we did see significant trends with thaw in certain bivariate correlations of $\mathrm{CH}_{4}$ fluxes such as temperature sensitivity, seasonality and effect of deepening frost table during the growing season. However, these trends were absent when multiple correlates were considered together, suggesting that dominant controls on $\mathrm{C}$ fluxes and their interactions, change variably as thaw progresses. 


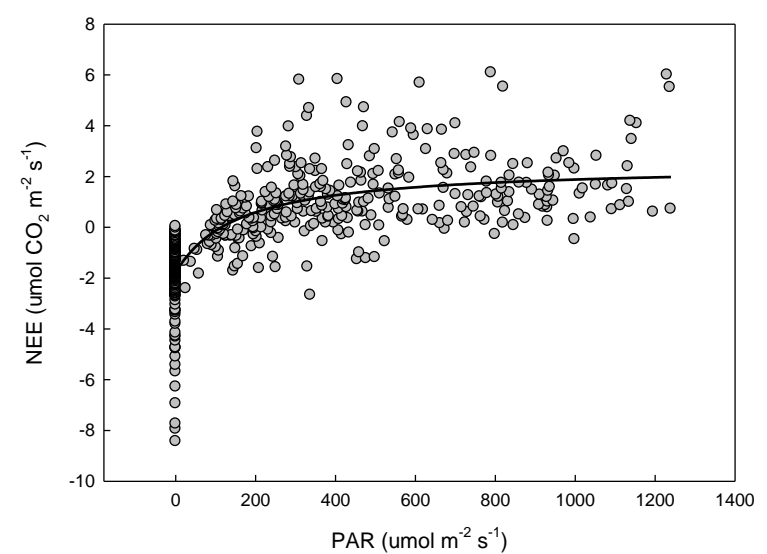

Figure 2. Rectangular hyperbola fit of site-level NEE with PAR $(n=525)$.

\subsection{Across peatland correlates of $\mathrm{C}$ fluxes}

Strongest environmental factors associated with the $\mathrm{CH}_{4}$ flux across all sampled collars were- elevation, water table depth, $\mathrm{pH}, \mathrm{VGA}$, thaw depth and surface water $\mathrm{C}: \mathrm{N}$. Each of these correlates is a possible proxy of one or more controls of temperature, moisture and substrate quantity and quality on $\mathrm{CH}_{4}$ flux. Our correlations support previous findings from various wetland types (as reviewed in Lai, 2009; Olefeldt et al., 2013; Turetsky et al., 2014). The multiple regression analysis of lumped data across Stordalen also showed similar trends to other temperate, boreal or arctic peatlands. For example, a peatland complex sampled in the discontinuous permafrost region of Manitoba, Canada by Bubier et al. (1995) showed a best fit model including WTD, water chemistry and vegetation variables explaining $81 \%$ of the variance in $\mathrm{CH}_{4}$ fluxes. Bubier et al. (1995) reported WTD as being the strongest individual correlate with the $\mathrm{CH}_{4}$ fluxes, but in our best fit model, WTD was not an important variable likely because the stages with little or no thaw had no water table. Elevation seems to be a better proxy for soil moisture (and other $\mathrm{CH}_{4}$ controls), showing the highest contribution to the best fit model (Table 2). Elevation has been previously recognized as an integrator of multiple structural changes resulting from permafrost thaw and is a potentially useful component of models estimating $\mathrm{C}$ flux in permafrost landscapes (Lee et al., 2011). Rerunning the best fit model without elevation decreases the overall model fit by $10 \%$ but increases the contribution of VGA to the model, while the contribution of thaw depth and soil temperature remain the same. Removal of elevation from the model better isolates the relative effects of thaw depth, temperature and VGA on $\mathrm{CH}_{4}$ fluxes and suggests that the strongest contribution is from VGA, followed by thaw depth and soil temperature. VGA is likely a strong effect as it is linked with spatial and seasonal changes in substrate availability, litter input and root exudates and thus

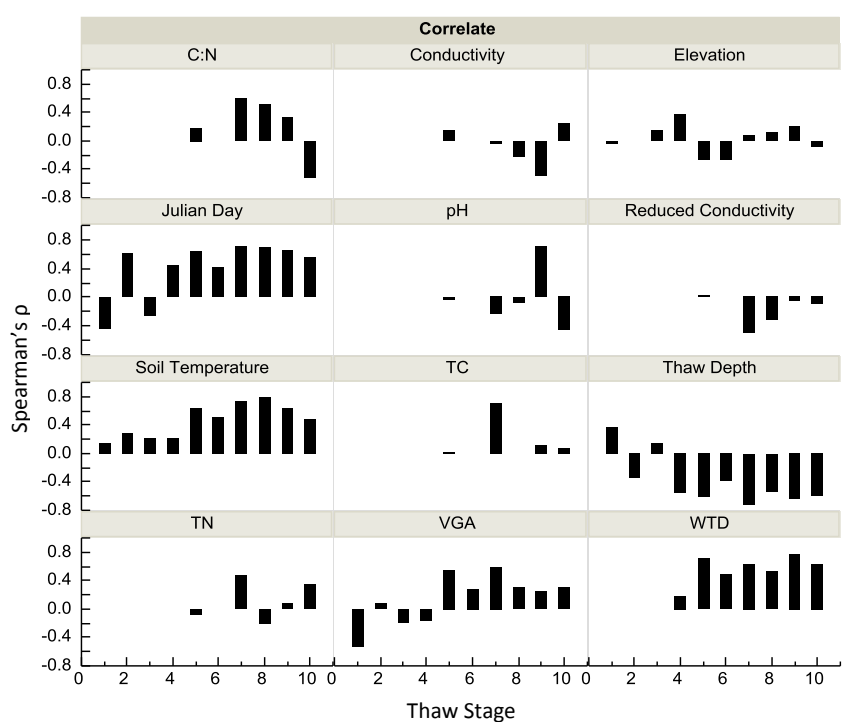

Figure 3. Correlation coefficients of $\mathrm{CH}_{4}$ flux with biotic and abiotic variables within thaw stages. Changing strength and directions of correlations are shown for thaw stages 1 to 10 ; where stage 1 is intact permafrost and stage 10 is fully thawed. Each data point represents a correlation analysis of $n=19$ days. The missing data points in WTD, conductivity, reduced conductivity, $\mathrm{pH}, \mathrm{TC}, \mathrm{TN}$ and $\mathrm{C}: \mathrm{N}$ (total carbon, nitrogen and $\mathrm{C}: \mathrm{N}$ in surface water) are from the thaw stages that did not have a water table or had a correlation coefficient of 0 .

relates to both spatial and temporal variability in $\mathrm{CH}_{4}$ flux (Whiting and Chanton, 1993).

Soil temperature and thaw depth are significant variables in our multiple regression model of $\mathrm{CH}_{4}$ flux, while Julian day is not. It may be that across the permafrost gradient, Julian day does not capture seasonality as well as a combination of thaw depth and soil temperature (Table 2), suggesting the role of the variable seasonal trajectories of thaw depth and soil temperature in the different thaw stages, for predicting $\mathrm{CH}_{4}$ flux.

As expected, PAR was the strongest correlate of NEE both in across peatland-lumped data and within thaw stage data. Using the rectangular hyperbola fit, Frolking et al. (1998) reported parameters from 13 peatland sites wherein PAR explained, on average, $68 \%$ (ranging from 47 to $89 \%$ ) of the variance in NEE. Comparatively our across peatland-lumped data fit to the rectangular hyperbola model explain a lower percent of the variance (52\%) in NEE, likely due to biases introduced by the high spatial heterogeneity on our site (Laine et al., 2009). WTD, thaw depth and soil temperature also show significant but weak relationships with $\mathrm{CO}_{2}$ fluxes. Vascular green area seems to be a better proxy than WTD, thaw depth and soil temperature for controls on $\mathrm{CO}_{2}$ fluxes, which makes sense as VGA represents the amount of photosynthesizing area as well as approximates above and belowground biomass which is related to autotrophic and het- 


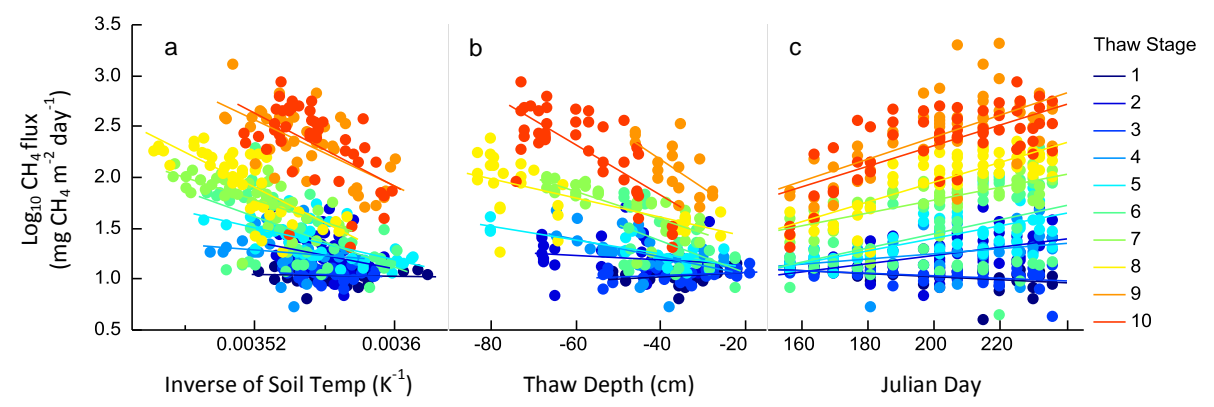

Figure 4. (a) Arrhenius plots for each thaw stage. (b) Linear fit between thaw depth and $\mathrm{CH}_{4}$ flux with progressing thaw. (c) Increase in seasonality of $\mathrm{CH}_{4}$ flux as the permafrost thaws.

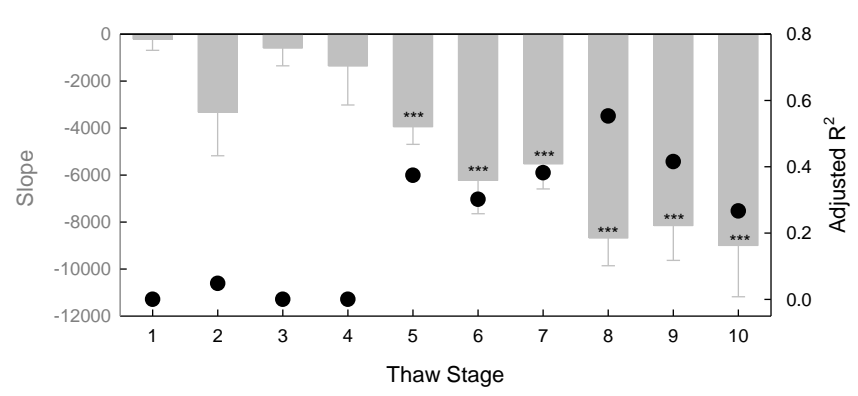

Figure 5. Slope and adjusted $R^{2}$ from the Arrhenius plots (Fig. 4a) of each thaw stage. The left $y$ axis is the estimate and standard error of the slope of the fit (represented by the gray bars \pm standard error) and the right y axis shows the $R^{2}$ of each fit (represented by the black dots). The significant regressions $(p<0.0001)$ are denoted by asterisk. Variance of $\mathrm{CH}_{4}$ fluxes explained by soil temperature generally increases and becomes more significant ( $p$ values) from less to more thawed stages. Slope of the soil temperature to $\mathrm{CH}_{4}$ flux relationship also increases with increased thaw.

erotrophic respiration (Schneider et al., 2011; Wilson et al., 2006).

\subsection{Trends with increasing thaw}

Bivariate relationships between correlates and $\mathrm{CH}_{4}$ flux progress variably as the permafrost thaws, although some significant trends of increasing correlations are seen in soil temperature, thaw depth and Julian day, as thaw progresses (Figs. 3, 4 and 5). We found that as the permafrost thaws, temperature sensitivity increases (Fig. 4a), increasing thaw depth has an increasing effect on $\mathrm{CH}_{4}$ fluxes (Fig. 4b), and there is a stronger seasonality effect (Fig. 4c). This trend of increasing correlation could be partly due to the increasing magnitude and variance of not only $\mathrm{CH}_{4}$ fluxes but also the environmental variables with thawing permafrost. Additionally, higher VGA later in the growing season could also be result in a stronger seasonality effect (Fig. 4c) in the later stages of thaw, especially as these stages had the highest sedge VGA. The Arrhenius plots of soil temperature and $\mathrm{CH}_{4}$ fluxes showed increased temperature sensitivity from less thawed to more thawed stages, with the slope and $R^{2}$ of this regression increasing (Fig. 5). Changing temperature sensitivity in our results contradicts results from YvonDurocher et al. (2014) that suggest a consistent temperature sensitivity of $\mathrm{CH}_{4}$ fluxes across scales. Apparent temperature sensitivity can be confounded due to changes in substrate availability (Kirschbaum, 2006). Increasing temperature sensitivity with thaw in our results could be related to higher substrate availability (supported by higher VGA) in thawed stages switching $\mathrm{CH}_{4}$ production from being substrate limited to becoming temperature limited. Lower temperature sensitivity in the intact permafrost could also be related to DOC quality. Olefeldt et al. (2012) report higher aromaticity in DOC exported from palsa and bog catchments at Stordalen compared to fen catchments and a high proportion of aromatic compounds in litter is generally associated with decreased temperature sensitivity (e.g., Erhagen et al., 2013). High temperature sensitivity in wetter sites has also been reported by Olefeldt et al. (2013) in a meta-analysis of $\mathrm{CH}_{4}$ emissions from terrestrial ecosystems worldwide. Christensen et al. (2003) found that temperature is a limiting factor only when the WTD is $10 \mathrm{~cm}$ or less below the surface, whereas a lower WTD is more sensitive to WTD fluctuations than to soil temperature fluctuations. This is generally supported in our results with stages 4 to 6 that have growing season mean WTD greater than $10 \mathrm{~cm}$ (Table 1) having lower sensitivity to WTD than stages 7 to 10 , though there is variability in both classes (Fig. 3). Our estimated temperature sensitivity for each thaw stage is the net effect of temperature on methanogenesis and methanotrophy and since we only measure the net $\mathrm{CH}_{4}$ flux we cannot isolate the relative temperature sensitivities for the two processes. Also interesting is the effect of the increasing thaw, over the growing season, on $\mathrm{CH}_{4}$ flux- more significant in the wetter more thawed stages than the drier intact permafrost stages (Figs. 3 and $4 \mathrm{~b}$ ). A similar trend was also emphasized in Olefeldt et al. (2013). The deepening frost table is related to temperature and thus could also represent the larger temperature sensitivity of $\mathrm{CH}_{4}$ in later thaw stages. Additionally, larger variance in thaw depths of later thaw stages could explain the 


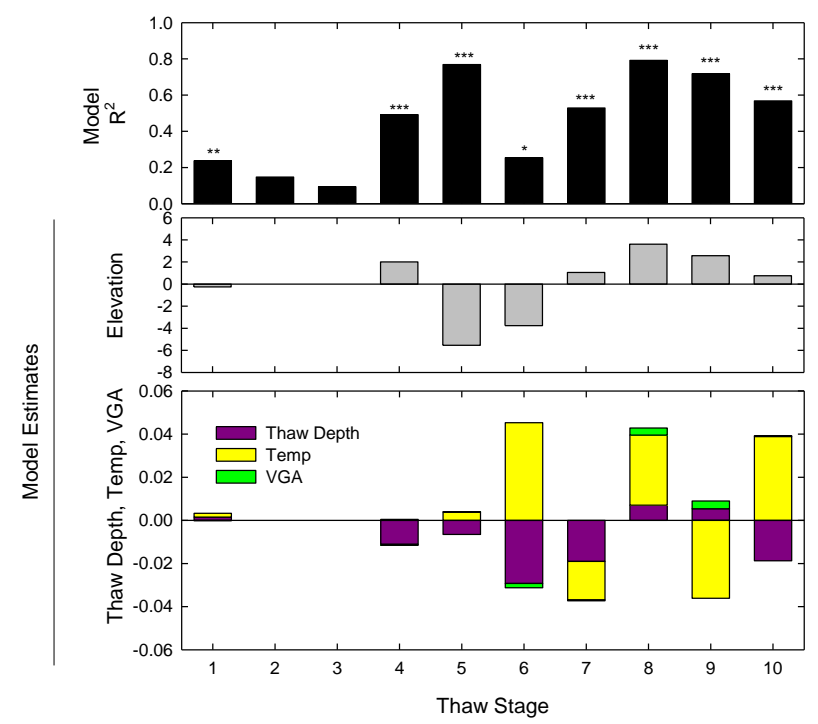

Figure 6. Multiple regression of $\mathrm{CH}_{4}$ fluxes with elevation, thaw depth, soil temperature (temp) and vascular green area (VGA) for each thaw stage (thaw stage $1=$ intact permafrost, $10=$ completely thawed). Model fit $R^{2}$ values are reported along with model estimates (stacked bars). Significance of the $R^{2}$ is denoted by asterisk ( ${ }^{*}$ for $p<0.05$, $^{* *}$ for $p<0.01$, and ${ }^{* * *}$ for $p<0.001$ ). Soil temperature was not a statistically significant estimate for any of the thaw stages. Elevation was significant for thaw stages 1, 4, 8 and 9; thaw depth for 1, 4, 5, 7, 8 and 10; and VGA for 8 and 9.

larger effect of thaw depth in these stages .The larger variance in thaw depth could be attributed to a steeper drop in thaw depths as the growing season progresses in the wetter thaw stages due to the dependence of thermal conductivity of peat on the degree of wetness (Quinton et al., 2009).

While bivariate relationships between correlates and $\mathrm{C}$ flux provide insight into the possible controls on these fluxes, multiple regressions better demonstrate the interactive nature of these correlates. Re-running the best fit model of the lumped data (Table 2) for each thaw stage showed that the strength of the overall model and the parameter estimates are variable along the thaw gradient (Fig. 6). While elevation had a strong effect in across peatland-lumped data, it makes sense that it was a significant effect only for a few within thaw stage analyses (thaw stages 1, 4, 8 and 9) because these stages had diverse habitats with spatially varying elevations. Soil temperature was not a statistically significant estimate for any of the thaw stages, possibly because elevation and thaw depth are better proxies for the long term thermal regime and also relate to several other controls of $\mathrm{CH}_{4}$ flux, as previously mentioned. VGA was only a significant effect within thaw stages 8 and 9. These results emphasize that spatial differences in elevation are not as important within thaw stages as they were in across peatland-lumped data. Also, thaw depth and VGA have variable effects but generally stronger in the thawed stages.
Similar to $\mathrm{CH}_{4}$ flux, the strength of the major correlate for $\mathrm{CO}_{2}$ flux (PAR) changes variably across the thaw gradient. While the across peatland relationship of NEE with temperature and PAR is weaker than that found in other peatland sites (e.g., Bubier et al., 2003), when broken down into thaw stages, the percent variance of NEE explained increases (up to $91 \%$; Table 4) for many thaw stages. The sample size for each thaw stages is different making it problematic to statistically compare the thaw stages. However, we found that the $R^{2}$ is not significantly correlated to the sample size for that thaw stage, suggesting that there are other factors increasing the control of PAR on NEE as permafrost thaws such as increased photosynthesizing biomass (reflected by increasing VGA and GPP). If VGA is no longer limiting, PAR sensitivity could be increasing as permafrost thaws. This is supported in the parameter fitting for each thaw stage (Table 4), the general trends observed are that the $\mathrm{CO}_{2}$ fixed at maximum PAR $\left(\mathrm{GP}_{\mathrm{MAX}}\right)$ increases as permafrost thaws as does the amount of $\mathrm{CO}_{2}$ fixed per unit of PAR $(\alpha)$, both of which could be related to increase in VGA but also the photosynthetic capacity change from plant species changes. The amount of respiration at $0{ }^{\circ} \mathrm{C}$ generally increases with thaw, which could be related to increasing substrate availability. Trends of increasing GPP and ecosystem respiration with permafrost thaw have been reported in previous studies (e.g., Dorrepaal et al., 2009; Hicks Pries et al., 2013). However, in our results these trends are not significant along the thaw gradient and progress variably.

\subsection{Relationship between $\mathrm{NEE}$ and $\mathrm{CH}_{4}$}

NEE is thought to be related to $\mathrm{CH}_{4}$ emissions due to the shared association with recently produced substrate availability, root exudates and turnover and litter input, and this link has been observed in several studies (Bellisario et al., 1999; Ström and Christensen, 2007; Whiting and Chanton, 1993 , etc.). In our thaw stages, there was also an overall significant and positive relationship between growing season averages of $\mathrm{GP}_{\mathrm{MAX}}$ and $\mathrm{CH}_{4}(\rho=0.56, p=0.0021$; Fig. 7). Interestingly, thaw stages 8 to 10 (graminoid dominated) have a different relationship of $\mathrm{GP}_{\mathrm{MAX}}$ and $\mathrm{CH}_{4}$ compared with thaw stages 1 to 7 (moss dominated) suggesting a shift in the partitioning of $\mathrm{C}$ loss from the system as $\mathrm{CO}_{2}$ or $\mathrm{CH}_{4}$ with increasing thaw and changing vegetation. We expected this shift to be related to an increase in graminoid VGA (increase in lability and $\mathrm{CH}_{4}$ emission via aerenchyma), which was supported by our data. Surprisingly, we also found the shift to be related to a loss of Sphagnum cover, perhaps due to an increase in $\mathrm{pH}$ and decrease in organic matter lability. Furthermore, there was a significant interaction between soil temperature and Sphagnum cover in a linear model explaining $\mathrm{CH}_{4}: \mathrm{CO}_{2}$, suggesting that the relationship of $\mathrm{CH}_{4}$ and $\mathrm{CO}_{2}$ depends on Sphagnum abundance but the effect of Sphagnum varies by temperature (Table 5). 


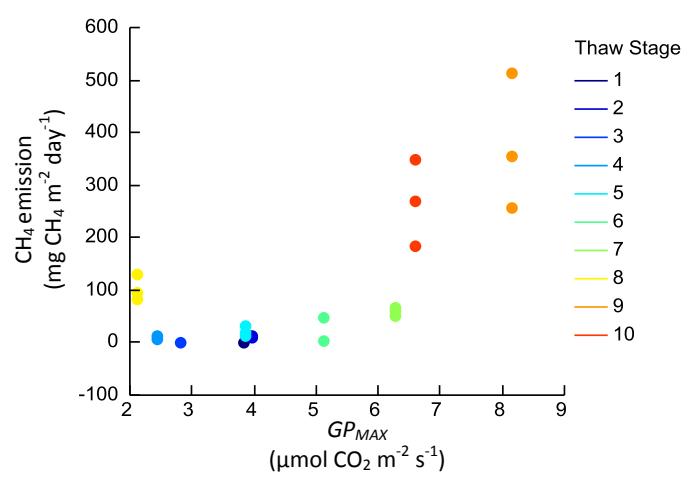

Figure 7. Relationship between growing season means of $\mathrm{CH}_{4}$ flux and $\mathrm{GP}_{\mathrm{MAX}}$ (gross photosynthetic $\mathrm{CO}_{2}$ capture at maximum PAR) across all thaw stages. Thaw stages 1 (intact permafrost) to 10 (thawed permafrost) are shown using blue to red colors, respectively.

\subsection{Variable changes in ecosystem relationships with increasing thaw}

Permafrost thaw increases magnitude and variance of $\mathrm{CO}_{2}$ and $\mathrm{CH}_{4}$ fluxes as well as changes the abiotic and biotic correlates of these fluxes. As a result, the relationships between the correlates and $\mathrm{C}$ fluxes change. While in the lumpedacross peatland data, spatially variable factors are the dominant correlates of $\mathrm{CO}_{2}$ and $\mathrm{CH}_{4}$ fluxes (elevation being the best proxy for thermal regime, soil moisture, VGA, etc.), within thaw stages it is the correlates with high temporal variations that play a critical role (Julian day, deepening frost table and soil temperature). The changing correlates of $\mathrm{CO}_{2}$ and $\mathrm{CH}_{4}$ fluxes are important to consider from a context of upscaling these processes from within thaw stage to site to landscape scales. Changing sensitivity of $\mathrm{CH}_{4}$ fluxes to temperature, likely related to a shift from substrate to temperature limitation going from low biomass and low nutrient palsa stages to high biomass and high nutrient thawed stages. Based on the range of temperature response curves of $\mathrm{CH}_{4}$ flux across the thaw gradient (Fig. 4a), applying one activation energy value to estimate landscape level $\mathrm{CH}_{4}$ fluxes at Stordalen would not be appropriate and would likely require a set of parameterizations for the various thaw stages. Variable temperature sensitivities to $\mathrm{C}$ fluxes have been recognized in major thaw stages in the past (e.g., Lupascu and Wadham, 2012), but our study demonstrates that this variability is present even in the transitional stages. Furthermore, the multiple regression analyses for each thaw stages (Fig. 6) demonstrated the changing relative importance and interactive effects of dominant correlates of $\mathrm{CH}_{4}$ flux highlighting that controls in transitional stages of permafrost thaw are not necessarily related to controls in adjacent or end-member stages.

Paleo-ecological methods were not employed to confirm the actual thaw status of the thaw stages used in our anal- yses. Rather, our space for time approach was employed to sample the major stages of thaw at Stordalen acknowledged in previous studies (Bäckstrand et al., 2010; Johansson et al., 2006; Svensson et al., 1999, etc.) - encompassing palsa (our stages 1 to 3 ), internal fen (our stages 4 to 6), completely thawed flow through fen (our stages 7 to 10) type habitats - while capturing the wide range of structural conditions within each of these 3 broad thaw stages. We acknowledge that structural changes due to thaw may progress variably and attempt to capture each of these pathways. For example, palsa may collapse abruptly into a wet sedge dominated habitat that then switches to a Sphagnum lawn (our thaw stage 1 progressing into stage 8 and then to stage 5). Alternatively, this progression can be gradual with a decrease in elevation of palsa (stage 1 to 2 and then 3 ), followed by progression into Sphagnum lawn (stage 4 and 5). Regardless, the focus of our study was the changing correlates of $\mathrm{C}$ fluxes along the thaw gradient and a proposed sequence of thaw stages was required to analyze these changes.

\section{Conclusions}

Our results on the environmental correlates of $\mathrm{C}$ fluxes interacting and changing variably with thaw suggest that using process based models or relationships between NEE and $\mathrm{CH}_{4}$ flux to derive landscape level $\mathrm{C}$ fluxes would require additional information about transitional thaw stages.

Peatlands in the discontinuous permafrost zone are highly heterogeneous, especially if they are actively thawing. Our research highlights the variability observed in structurefunction relationships with permafrost thaw. Additionally, by identifying across peatland structure-function relationships that are maintained across the heterogeneous landscape our results will assist in improving regional estimates of the carbon balance and provide insight into the level of aggregation or disaggregation needed in models to capture ecosystem level response to change.

Acknowledgements. We gratefully acknowledge valuable equipment, lab and field assistance from Tom Parker, Silvie Harder, Étienne Fluet-Chouinard, Paul Wilson, Christina Puzzolo, Mike Dalva, Patrick Crill, Ruth Varner, Samantha Werner, Carmody McCalley and Niklas Rakos and elevation data from Andreas Persson. We also thank the staff at Abisko Scientific Research Station, Sweden. The research was supported by a James McGill Professorship Stipend to N. T. Roulet, a Discovery Grant and a Strategic Project Grant from the Natural Sciences and Engineering Research Council of Canada (NSERC) to N. T. Roulet The research was also supported by the Global Environmental and Climate Change Regroupement stratégique graduate stipend to A. Malhotra funded by the Fonds de recherche du Québec Nature et technologies (FQRNT), McGill University Geography Department funding to A. Malhotra and a PhD research scholarship to A. Malhotra from FQRNT.

Edited by: J. Vonk 


\section{References}

Bäckstrand, K., Crill, P. M., Jackowicz-Korczyñski, M., Mastepanov, M., Christensen, T. R., and Bastviken, D.: Annual carbon gas budget for a subarctic peatland, Northern Sweden, Biogeosciences, 7, 95-108, doi:10.5194/bg-7-95-2010, 2010.

Bellisario, L., Bubier, J. L., and Moore, T.: Controls on $\mathrm{CH}_{4}$ emissions from a northern peatland, Global Biogeochem. Cy., 13, 8191, 1999.

Belshe, E. F., Schuur, E. A. G., Bolker, B. M., and Bracho, R.: Incorporating spatial heterogeneity created by permafrost thaw into a landscape carbon estimate, J. Geophys. Res., 117, G01026, doi:10.1029/2011JG001836, 2012.

Bubier, J. L., Moore, T. R., Bellisario, L., Comer, N. T., and Crill, P. M.: Ecological controls on methane emissions from a northern peatland complex in the zone of discontinuous permafrost, Manitoba, Canada, Global Biogeochem. Cy., 9, 455-470, 1995.

Bubier, J. L., Bhatia, G., Moore, T., Roulet, N., and Lafleur, P.: Spatial and temporal variability in growing-season net ecosystem carbon dioxide exchange at a large peatland in Ontario, Canada, Ecosystems, 6, 353-367, 2003.

Callaghan, T. V., Bergholm, F., Christensen, T. R., Jonasson, C., Kokfelt, U., and Johansson, M.: A new climate era in the subArctic: Accelerating climate changes and multiple impacts, Geophys. Res. Lett., 37, 1-6, 2010.

Camill, P.: Patterns of boreal permafrost peatland vegetation across environmental gradients sensitive to climate warming, Can. J. Bot., 77, 721-733, 1999.

Camill, P.: Permafrost Thaw Accelerates in Boreal Peatlands During Late-20th Century Climate Warming, Clim. Change, 68, 135-152, 2005.

Camill, P., Lynch, J. A., Clark, J. S., Adams, J. B., and Jordan, B.: Changes in Biomass, Aboveground Net Primary Production, and Peat Accumulation following Permafrost Thaw in the Boreal Peatlands of Manitoba, Canada, Ecosystems, 4, 461-478, 2001.

Christensen, T. R., Ekberg, A., Ström, L., Mastepanov, M., Panikov, N., Oquist, M., Svensson, B. H., Nykänen, H., Martikainen, P. J., and Oskarsson, H.: Factors controlling large scale variations in methane emissions from wetlands, Geophys. Res. Lett., 30, 1414, doi:10.1029/2002GL016848, 2003.

Christensen, T. R., Johansson, T. R., Akerman, H. J., Mastepanov, M., Malmer, N., Friborg, T., Crill, P., and Svensson, B. H.: Thawing sub-arctic permafrost: Effects on vegetation and methane emissions, Geophys. Res. Lett., 31, L04501, doi:10.1029/2003GL018680, 2004.

Dorrepaal, E., Toet, S., van Logtestijn, R. S. P., Swart, E., van de Weg, M. J., Callaghan, T. V., and Aerts, R.: Carbon respiration from subsurface peat accelerated by climate warming in the subarctic, Nature, 460, 616-619, 2009.

Erhagen, B., Öquist, M., Sparrman, T., Haei, M., Ilstedt, U., Hedenström, M., Schleucher, J., and Nilsson, M. B.: Temperature response of litter and soil organic matter decomposition is determined by chemical composition of organic material, Glob. Change Biol., 19, 3858-71, 2013.

Frolking, S., Bubier, J. L., Moore, T., Ball, T., Bellisario, L., Bhardwaj, A., Carroll, P., Crill, P., Lafleur, P., McCaughey, J. H., Roulet, N., Suyker, A., Verma, S., Waddington, J., and Whiting, G.: Relationship between ecosystem productivity and photosynthetically active radiation for northern peatlands, Global Biogeochem. Cy., 21, 115-126, 1998.
Hicks Pries, C. E., Schuur, E. A. G., and Crummer, K. G.: Thawing permafrost increases old soil and autotrophic respiration in tundra: partitioning ecosystem respiration using $\delta^{13} \mathrm{C}$ and $\delta^{14} \mathrm{C}$, Glob. Change Biol., 19, 649-61, 2013.

Hines, M. E., Duddleston, K. N., Rooney-Varga, J. N., Fields, D., and Chanton, J. P.: Uncoupling of acetate degradation from methane formation in Alaskan wetlands: Connections to vegetation distribution, Global Biogeochem. Cy., 22, 1-12, 2008.

Hodgkins, S. B., Tfaily, M. M., McCalley, C. K., Logan, T. A., Crill, P. M., Saleska, S. R., Rich, V. I., and Chanton, J. P.: Changes in peat chemistry associated with permafrost thaw increase greenhouse gas production., Proc. Natl. Acad. Sci. USA, 111, 581924,2014

Johansson, T., Malmer, N., Crill, P. M., Friborg, T., Åkerman, J. H., Mastepanov, M., and Christensen, T. R.: Decadal vegetation changes in a northern peatland, greenhouse gas fluxes and net radiative forcing, Glob. Change Biol., 12, 2352-2369, 2006.

Kirschbaum, M.: The temperature dependence of organic-matter decomposition - still a topic of debate, Soil Biol. Biochem., 38, 2510-2518, 2006.

Kvillner, E. and Sonesson, M.: Plant Distribution and Environment of a Subarctic Mire, Ecol. Bull., 30, 97-111, 1980.

Lai, D. Y. F.: Methane Dynamics in Northern Peatlands: A Review, Pedosphere, 19, 409-421, 2009.

Lai, Y. F.: Spatial and Temporal Variations of Carbon Dioxide and Methane Fluxes Measured by Autochambers at the Mer Bleue Bog, PhD thesis, McGill University, Montreal, Canada, 2012.

Laine, A., Riutta, T., Juutinen, S., Väliranta, M., and Tuittila, E.-S.: Acknowledging the spatial heterogeneity in modelling/reconstructing carbon dioxide exchange in a northern aapa mire, Ecol. Modell., 220, 2646-2655, 2009.

Lee, H., Schuur, E. A. G., Vogel, J. G., Lavoie, M., Bhadra, D., and Staudhammer, C. L.: A spatially explicit analysis to extrapolate carbon fluxes in upland tundra where permafrost is thawing, Glob. Change Biol., 17, 1379-1393, 2011.

Lee, H., Schuur, E. A. G., Inglett, K. S., Lavoie, M., and Chanton, J. P.: The rate of permafrost carbon release under aerobic and anaerobic conditions and its potential effects on climate, Glob. Change Biol., 18, 515-527, 2012.

Luoto, M., Heikkinen, R. K., and Carter, T. R.: Loss of palsa mires in Europe and biological consequences, Environ. Conserv., 31, 30-37, 2004.

Lupascu, M. and Wadham, J.: Temperature sensitivity of methane production in the permafrost active layer at Stordalen, Sweden: A comparison with non-permafrost northern wetlands, Arctic, Antarct. Alp. Res., 44, 469-482, 2012.

Mackelprang, R., Waldrop, M. P., DeAngelis, K. M., David, M. M., Chavarria, K. L., Blazewicz, S. J., Rubin, E. M., and Jansson, J. K.: Metagenomic analysis of a permafrost microbial community reveals a rapid response to thaw, Nature, 480, 368-371, 2011.

Malmer, N., Johansson, T., Olsrud, M., and Christensen, T. R.: Vegetation, climatic changes and net carbon sequestration in a NorthScandinavian subarctic mire over 30 years, Glob. Change Biol., 11, 1895-1909, 2005.

McCalley, C., Woodcroft, B., Hodgkins, S., Wehr, R., Kim, E.H., Mondav, R., Crill, P., Chanton, J., Rich, V., Tyson, G., and Saleska, S.: Methane dynamics regulated by microbial community response to permafrost thaw, Nature, 514, 478-481, 2014. 
McConnell, N. A., Turetsky, M. R., David McGuire, A., Kane, E. S., Waldrop, M. P., and Harden, J. W.: Controls on ecosystem and root respiration across a permafrost and wetland gradient in interior Alaska, Environ. Res. Lett., 8, 045029, doi:10.1088/17489326/8/4/045029, 2013

Morrissey, L. and Livingston, G.: Methane emissions from Alaska arctic tundra: An assessment of local spatial variability, J. Geophys. Res., 97, 661-670, 1992.

Olefeldt, D. and Roulet, N. T.: Effects of permafrost and hydrology on the composition and transport of dissolved organic carbon in a subarctic peatland complex, J. Geophys. Res., 117, G01005, doi:10.1029/2011JG001819, 2012.

Olefeldt, D. and Roulet, N. T.: Permafrost conditions in peatlands regulate magnitude, timing, and chemical composition of catchment dissolved organic carbon export, Glob. Change Biol., 20, 3122-3136, 2014.

Olefeldt, D., Turetsky, M. R., Crill, P. M., and McGuire, A. D.: Environmental and physical controls on northern terrestrial methane emissions across permafrost zones., Glob. Change Biol., 19, 589-603, 2013.

Osterkamp, T.: The recent warming of permafrost in Alaska, Glob. Planet. Change, 49, 187-202, 2005.

Quinton, W., Hayashi, M., and Chasmer, L.: Peatland hydrology of discontinuous permafrost in the Northwest Territories: overview and synthesis, Can. Water Resour. J., 34, 311-328, 2009

Schneider, J., Kutzbach, L., and Wilmking, M.: Carbon dioxide exchange fluxes of a boreal peatland over a complete growing season, Komi Republic, NW Russia, Biogeochemistry, 111, 485513, 2011

Schuur, E. A. G., Bockheim, J., Canadell, J. G., Euskirchen, E., Field, C. B., Goryachkin, S. V., Hagemann, S., Kuhry, P., Lafleur, P. M., Lee, H., Mazhitova, G., Nelson, F. E., Rinke, A., Romanovsky, V. E., Shiklomanov, N., Tarnocai, C., Venevsky, S., Vogel, J. G., and Zimov, S. A.: Vulnerability of Permafrost Carbon to Climate Change: Implications for the Global Carbon Cycle, Bioscience, 58, 701-714, 2008.

Schuur, E. A. G., Abbott, B. W., Bowden, W. B., Brovkin, V., Camill, P., Canadell, J. G., Chanton, J. P., Chapin, F. S., Christensen, T. R., Ciais, P., Crosby, B. T., Czimczik, C. I., Grosse, G., Harden, J., Hayes, D. J., Hugelius, G., Jastrow, J. D., Jones, J. B., Kleinen, T., Koven, C. D., Krinner, G., Kuhry, P., Lawrence, D. M., McGuire, a. D., Natali, S. M., O’Donnell, J. a., Ping, C. L., Riley, W. J., Rinke, A., Romanovsky, V. E., Sannel, a. B. K., Schädel, C., Schaefer, K., Sky, J., Subin, Z. M., Tarnocai, C., Turetsky, M. R., Waldrop, M. P., Walter Anthony, K. M., Wickland, K. P., Wilson, C. J., and Zimov, S. a.: Expert assessment of vulnerability of permafrost carbon to climate change, Clim. Change, 119, 359-374, 2013

Sitch, S., McGuire, A., and Kimball, J.: Assessing the carbon balance of circumpolar Arctic tundra using remote sensing and process modeling, Ecol. Appl., 17, 213-234, 2007.

Smith, L. C., Beilman, D. W., Kremenetski, K. V., Sheng, Y., MacDonald, G. M., Lammers, R. B., Shiklomanov, A. I., and Lapshina, E. D.: Influence of permafrost on water storage in West Siberian peatlands revealed from a new database of soil properties, Permafr. Periglac. Process., 23, 69-79, 2012.
Ström, L. and Christensen, T. R.: Below ground carbon turnover and greenhouse gas exchanges in a sub-arctic wetland, Soil Biol. Biochem., 39, 1689-1698,2007.

Svensson, B. H., Christensen, T. R., Johansson, E., and Oquist, M.: Interdecadal Changes in $\mathrm{CO}_{2}$ and $\mathrm{CH}_{4}$ Fluxes of a Subarctic Mire: Stordalen Revisited after 20 Years, Oikos, 85, 22-30, 1999.

Tarnocai, C., Canadell, J. G., Schuur, E. A. G., Kuhry, P., Mazhitova, G., and Zimov, S.: Soil organic carbon pools in the northern circumpolar permafrost region, Global Biogeochem. Cy., 23, GB2023, doi:10.1029/2008GB003327, 2009.

Treat, C. C., Wollheim, W. M., Varner, R. K., Grandy, A. S., Talbot, J., and Frolking, S.: Temperature and peat type control $\mathrm{CO}_{2}$ and $\mathrm{CH}_{4}$ production in Alaskan permafrost peats, Glob. Change Biol., 20, 2674-86, 2014.

Turetsky, M. R.: Decomposition and Organic Matter Quality in Continental Peatlands: The Ghost of Permafrost Past, Ecosystems, 7, 740-750, 2004.

Turetsky, M. R., Wieder, R. K., Vitt, D. H., Evans, R. J., and Scott, K. D.: The disappearance of relict permafrost in boreal north America: Effects on peatland carbon storage and fluxes, Glob. Change Biol., 13, 1922-1934, 2007.

Turetsky, M. R., Kotowska, A., Bubier, J. L., Dise, N. B., Crill, P., Hornibrook, E. R. C., Minkkinen, K., Moore, T. R., MyersSmith, I. H., Nykänen, H., Olefeldt, D., Rinne, J., Saarnio, S., Shurpali, N., Tuittila, E.-S., Waddington, J. M., White, J. R., Wickland, K. P., and Wilmking, M.: A synthesis of methane emissions from 71 northern, temperate, and subtropical wetlands, Glob. Change Biol., 20, 2183-97, 2014.

Vitt, D. H., Halsey, L. A., and Zoltai, S. C.: The changing landscape of Canada's western boreal forest: the current dynamics of permafrost, Can. J. For. Res., 30, 283-287, 2000.

Vogel, J., Schuur, E. A. G., Trucco, C., and Lee, H.: Response of $\mathrm{CO}_{2}$ exchange in a tussock tundra ecosystem to permafrost thaw and thermokarst development, J. Geophys. Res., 114, G04018, doi:10.1029/2008JG000901, 2009.

Whiting, G. and Chanton, J.: Primary production control of methane emission from wetlands, Nature, 364, 794-795, 1993.

Wilson, D., Alm, J., Riutta, T., Laine, J., Byrne, K. A., Farrell, E. P., and Tuittila, E.-S.: A high resolution green area index for modelling the seasonal dynamics of $\mathrm{CO}_{2}$ exchange in peatland vascular plant communities, Plant Ecol., 190, 37-51, 2006.

Ye, R., Jin, Q., Bohannan, B., Keller, J. K., McAllister, S. A., and Bridgham, S. D.: pH controls over anaerobic carbon mineralization, the efficiency of methane production, and methanogenic pathways in peatlands across an ombrotrophicminerotrophic gradient, Soil Biol. Biochem., 54, 36-47, doi:10.1016/j.soilbio.2012.05.015, 2012.

Yvon-Durocher, G., Allen, A. P., Bastviken, D., Conrad, R., Gudasz, C., St-Pierre, A., Thanh-Duc, N., and del Giorgio, P. A.: Methane fluxes show consistent temperature dependence across microbial to ecosystem scales, Nature, 507, 488-91, 2014.

Zhang, Y., Sachs, T., Li, C., and Boike, J.: Upscaling methane fluxes from closed chambers to eddy covariance based on a permafrost biogeochemistry integrated model, Glob. Change Biol., 18, 1428-1440, 2012. 